\title{
Peningkatan Pendapatan Rumah Tangga Melalui Pemberdayaan Ibu-Ibu PKK di Kota Kudus
}

\author{
Mia Ajeng Alifiana \\ Fakultas Ekonomi dan Bisnis, Universitas Muria Kudus \\ mia.ajeng@umk.ac.id
}

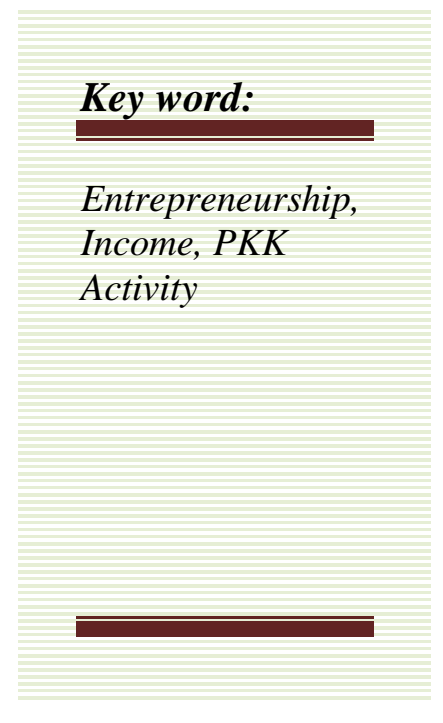

\begin{abstract}
The aim of this dedication is to train the PKK member to make accessories and increase their family income. The partner of this dedication is RT 01 RW 07 in Mlati Norowoti Village, Kudus Regency, especially the PKK group. The methods using in this service are entrepreneurship counseling and training in making hijab handmade accessories. PKK Group was delighthened with this program. They can practice making the accessories from acrylic based. The result of this dedication to the people activity was the PKK group Rt 01 Rw 07, the village of Mlati Norowito has been able to practice and make hijab handmade accessories until it reaches the marketing stage. The accessories have been sold among the member and also the resident of RT 01 RW 07 Mlati Nororwito and it become additional income for the family.
\end{abstract}

Kata Kunci

Kewirausahaan,

Penghasilan,

Kegiatan PKK

\section{Abstrak}

Tujuan dari pengabdian ini adalah untuk melatih anggota PKK agar mahir membuat aksesoris hijab dan meningkatkan pendapatan keluarga mereka. Mitra dedikasi ini adalah RT $01 \mathrm{RW}$ 07 di Desa Mlati Norowoti, Kabupaten Kudus, khususnya kelompok PKK. Metode yang digunakan dalam layanan ini adalah konseling dan pelatihan kewirausahaan dalam membuat aksesoris hijab buatan tangan. Kelompok PKK merasa senang dengan program ini. Mereka dapat berlatih membuat aksesoris dari bahan dasar akrilik. Hasil dari pengabdian kepada masyarakat ini adalah kelompok PKK RT 01 RW 07, Desa Mlati Norowito mampu berlatih dan membuat aksesoris hijab buatan tangan hingga mencapai tahap pemasaran. Asesoris telah dijual di antara anggota dan juga warga RT 01 RW 07 Mlati Nororwito dan itu menjadi penghasilan tambahan bagi keluarga. 


\section{PENDAHULUAN}

PKK terkenal akan 10 program pokoknya yang pada hakekatnya merupakan kebutuhan dasar manusia yaitu: 1) Penghayatan dan pengamalan Pancasila, 2) Gotong royong, 3) Pangan, 4) Sandang, 5) Perumahan dan tatalaksana rumah tangga, 6) Pendidikan dan keterampilan, 7) Kesehatan, 8) Pengembangan kehidupan berkoperasi, 9) Kelestarian lingkungan hidup, 10) Perencanaan sehat.

Kecamatan Kota merupakan salah satu kecamatan di Kabupaten Kudus, dimana sebagian besar penduduknya bermata pencaharian sebagai buruh industri dan swasta. Masyarakat Kecamatan Kota mendapat ruang gerak yang lebih fleksibel dalam upaya peningkatan perekonomian keluarga. Kelurahan Mlati Norowito merupakan salah satu wilayah administrative yang terdapat di Kecamatan Kota, dengan Iwan Elliardi selaku Kepala Kelurahan (Koran Muria, 17-11-2015) menyatakan bahwa meskipun Kelurahan Mlati Norowito berada di Kecamatan Kota, tetapi perhatian yang diperoleh masih sedikit terkait dengan kegiatan pembangunan atau kemasyarakatan, salah satu contoh nya adalah program kegiatan PKK.

Minarti selaku ketua PKK RT 01, RW 07, Kelurahan Mlati Norowito (November 2016) menyatakan bahwa pelaksanaan kegiatan PKK umumnya hanya sebagai ajang silaturahmi ibu-ibu warga kelurahan, belum diikuiti dengan peningkatan mutu hidup keluarga serta peran wanita secara mandiri dalam pembangunan kelurahan melalui kegiatan kewirausahaan (entrepreneurship), yang akan berdampak langsung pada peningkatan perekonomian rumah tangga.

Kewirausahaan adalah cara berpikir, cara menelaah, dan cara bertindak yang mengacu pada peluang dalam bisnis, pendekatan secara menyeluruh dan kepemimpingan berimbang. (Timmons dan Spinelli, 2004). Didalam kewirausahaan terdapat tuntutan untuk mengambil resiko pada setiap keputusan yang diambil. kewirausahaan mencakup proses kegiatan yang dibutuhkan untuk menciptakan atau melaksanakan suatu peluang pada saat semua pasar belum terbentuk atau belum teridentifikasi dengan jelas, atau komponen fungsi produksinya belum diketahui sepenuhnya. Sedangkan Kasmir pada tahun 2006 mengatakan bahwa kewirausahaan adalah suatu kemampuan kreativitas dan inovasi yang terus-menerus dalam hal menciptakan kegiatan usaha.

Ciri-ciri seorang wirausaha menurut Prof. Dr. H. Buchari Alma (2010) yaitu memiliki percaya diri, memiliki visi misi dan tujuan yang terukur, mempunyai jiwa kepemimpinan, memiliki karakter orisinil, 
memiliki karakter inisiatif, memiliki keberanian dalam mengambil resiko, memiliki komitmen, memiliki korelasi yang baik, memiliki jiwa tanggung jawab, memiliki jiwa produktif, dan memiliki sikap kerja keras.

Faktor kegagalan dalam berwirausaha adalah sbb.: 1) Tidak kompeten dalam manajerial dan pengelolaan usaha; 2) Kurang pengalaman dalam mengkoordinasikan, mengelola SDM, dan mengintegrasikan operasional perusahaan; 3) Kurang dapat mengendalikan keuangan; 4) Gagal dalam perencanaan; 5) Lokasi usaha yang tidak memadai dan kurang strategis; 6) Kurangnya pengawasan peralatan; 7) Sikap yang kurang sungguh-sungguh dalam berusaha; 8) Ketidakmampuan melakukan peralihan/ transisi kewirausahaan.

Berdasarkan uraian di atas dapat dikemukakan permasalahan di Kelurahan Mlati Norowito, Kec. Kota, Kab. Kudus adalah: "Bagaimanakah pemberdayaan ibuibu PKK di Kelurahan Mlati Norowito dalam rangka meningkatkan pendapatan keluarga?"

Berdasar permasalahan di atas, tujuan dari pengabdian ini adalah untuk memberdayakan ibu-ibu PKK di Kelurahan Mlati Norowito dalam rangka meningkatkan pendapatan keluarga.
Dengan adanya penyuluhan kewirausahaan serta pemberdayaan sumber daya yang tepat, maka visi Kabupaten Kudus dhi. mewujudkan Kudus yang semakin sejahtera melalui pemberdayaan ibu-ibu PKK untuk meningkatkan pendapatan rumah tangga dapat terwujud.

Penulis berharap hasil dari pengabdian ini dapat membekali ibu-ibu PKK di Kelurahan Mlati Norowito dengan pengetahuan tentang kewirausahaan dan ketrampilan membuat aksesoris handmade untuk hijab dari bahan acrylic, yang akan laku dijual untuk menambah pendapatan keluarga.

\section{METODE PELAKSANAAN}

Metode yang digunakan dalam kegiatan Pengabdian Kepada Masyarakat tersebut adalah presentasi penyuluhan kewirausahaan, dan praktek pembekalan warga dengan ketrampilan pembuatan aksesories handmade. Tahapan dalam pelaksanaan pengabdian dibagi menjadi dua yaitu tahap persiapan dan tahap pelaksanaan.

Tahap persiapan dilakukan pada bulan November 2016, yakni sebulan sebelum dilaksanakan Penyuluhan Kewirausahaan: "Pemberdayaan Ibu-Ibu PKK di Kelurahan Mlati Norowito dalam Rangka Meningkatkan Pendapatan Keluarga". Persiapan tersebut meliputi: 
a) Observasi dan survei ke Kelurahan Mlati Norowito, termasuk pengurusan perijinan untuk melaksanakan kegiatan Pengabdian Kepada Masyarakat.

b) Pemantapan konsep Pengabdian Kepada Masyarakat yang berupa penyuluhan kewirausahaan disertai pembekalan ketrampilan pembuatan aksesories handmade untuk hijab dari bahan acrylic, dalam wadah komunitas ibu-ibu PKK RW 7 Kelurahan Mlati Norowito.

c) Pembuatan instrumen pelaksanaan kegiatan Pengabdian Kepada Masyarakat, berupa handout presentasi dan sampel aksesories handmade untuk hijab dari bahan acrylic.

d) Persiapan alat dan bahan, terdiri dari: 1) Alat dan bahan presentasi; 2) Alat dan bahan pembuatan aksesories handmade untuk hijab dari bahan acrylic.

e) Perencanaan proses pembuatan media bantu yang dimaksud adalah dengan menyediakan handout langkah-langkah pembuatan aksesories handmade untuk hijab dari bahan acrylic.

\section{HASIL DAN PEMBAHASAN}

Pelaksanaan kegiatan Pengabdian Kepada Masyarakat dilakukan dalam wadah komunitas ibu-ibu PKK RW 7 Kelurahan Mlati Norowito, tepatnya di rumah Listiyaningsih yakni seorang warga RW 7, yang beralamat di Mlati Norowito Gang 7 RT 01 RW 7 No. 124A Kecamatan Kota Kabupaten Kudus 59319.
Kegiatan tersebut di atas telah mendapat persetujuan dari Iwan Elliarde, SE. selaku Lurah Mlati Norowito, Yunisih selaku Ketua PKK RW 7, dan Listiyaningsih selaku tuan rumah. Kegiatan tersebut dihadiri oleh 58 orang peserta PKK RW 7 Kelurahan Mlati Norowito, dan 5 orang dari Universitas Muria Kudus.

Urutan pelaksanaan kegiatan Pengabdian Kepada Masyarakat tersebut yang merupakan bagian dari acara PKK Ibu-Ibu RW 7 Kelurahan Mlati Norowito adalah sebagai berikut:

a) Pembukaan, serta menyanyikan lagu Mars PKK, Mars Kerja Bakti, dan Mars Keluarga Berencana oleh seluruh peserta PKK RW 7.

b) Sambutan Ketua PKK RW 7.

c) Penyuluhan kewirausahaan: "Pemberdayaan Ibu-Ibu PKK di Kelurahan Mlati Norowito Dalam Rangka Meningkatkan Pendapatan Keluarga"

d) Praktek pembekalan pembuatan aksesories handmade untuk hijab dari bahan acrylick bagi seluruh peserta PKK RW 7, dibantu oleh mahasiswa Universitas Muria Kudus.

e) Penutup dengan foto bersama antara pengurus PKK RW 7 dan pihak Universitas.

Penyusunan materi kegiatan Pengabdian Kepada Masyarakat ini 
dilakukan secara sederhana sehingga mudah dipahami oleh sasaran kegiatan, yaitu ibu-ibu PKK RW 7 Kelurahan Mlati Norowito yang dominan sebagai ibu rumah tangga. Materi yang diberikan terdiri dari:

a) Penyuluhan kewirausahaan "Pemberdayaan Ibu-Ibu PKK di Kelurahan Mlati Norowito Dalam Rangka Meningkatkan Pendapatan Keluarga."

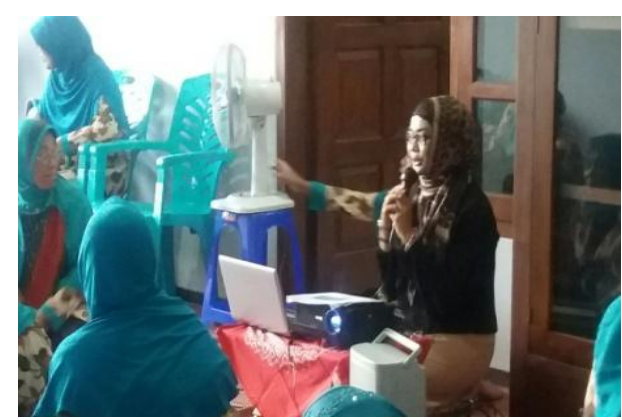

Gambar 1: Penyuluhan Kewirausahaan

b) Pembekalan warga dengan praktek pembuatan aksesories handmade untuk hijab dari bahan acrylic.

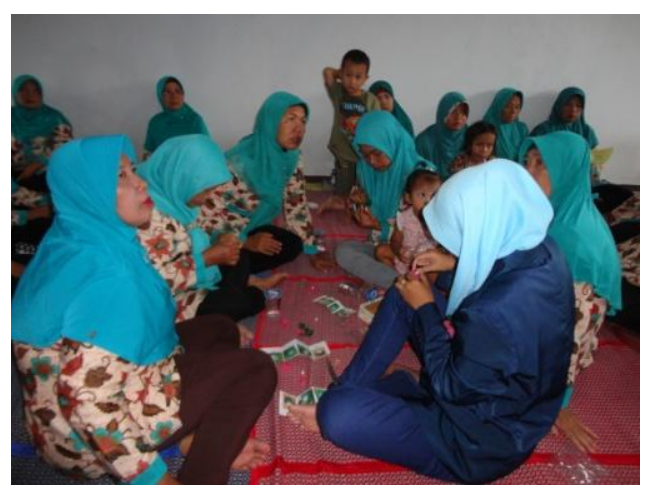

Gambar 2: Praktek pembuatan aksesories Penyuluhan kewirausahan dengan judul "Pemberdayaan Ibu-Ibu PKK di
Kelurahan Mlati Norowito Dalam Rangka Meningkatkan Pendapatan Keluarga" dilakukan dengan metode presentasi, yang terdiri dari pendahuluan, maksud dan tujuan, serta uraian materi kewirausahaan.

Pada saat penyuluhan dilakukan, tampak antusias ibu-ibu PKK RW 7 Kelurahan Mlati Norowito untuk dapat berperan serta dalam meningkatkan pendapatan keluarganya. Beberapa peserta PKK bahkan sudah turut berperan serta dalam peningkatan pendapatan keluarga, diantaranya dengan membuka warung kelontong, memanfaatkan bank sampah, dan berjualan di pasar. Namun, beberapa peserta lainnya menyatakan bahwa untuk membantu meningkatkan pendapatan keluarga, dengan memulai suatu usaha terkendala pada ide dan modal awal.

Penyuluhan yang diberikan memberikan pemahaman ke warga tentang arti, maksud dan tujuan dari kewirausahaan, serta sikap dan tahapan dalam kewirausahaan. Pengertian dari kewirausahaan adalah proses mengidentifikasi, mengembangkan dan membawa visi ke dalam kehidupan. Visi tersebut dapat berupa ide inovatif, peluang, cara yang lebih baik dalam menjalankan sesuatu. Dimana hasil akhir dari proses tersebut adalah penciptaan usaha baru yang dibentuk pada kondisi risiko/ ketidakpastian. 
Memulai suatu usaha, disarankan untuk dapat menciptakan visi dari kondisi lingkungan sekitar, terutama dengan mencoba memenuhi permintaan pasar yang ada secara sederhana. Dan di awal usaha disarankan untuk dapat memulai usaha dengan modal sendiri, patungan atau justru tanpa modal yakni dengan sistem menjadi reseller/ makelar/ perantara terjadinya penjualan. Sehingga hutang sangat tidak disarankan dalam memulai suatu usaha.

Pelatihan yang diberikan setelah penyuluhan kewirausahaan adalah praktek pembuatan aksesories handmade untuk hijab dari bahan acrylick, yang bahannya dapat diperoleh di toko aksesories dengan harga terjangkau. Aksesories tersebut dapat dijual di pasaran dengan laba maksimal sampai dengan $100 \%$ dari biaya produksi, jika dipasarkan pada pasar yang tepat.

Berikut adalah langkah pembuatan aksesories hijab dari bahan acrylick:

a) Tahap Persiapan

- Cek model berdasarkan keinginan pasar

- Penyediaan bahan: senar/nilon, daun dan kelopak acrylic, mutiara plastiK, lempengan dan peniti

b) Tahapan produksi

- Penyusunan daun hijau pada lempengan sebanyak 15 Buah

- Penyusunan kelopak besar warna pink sebanyak 6 buah
- Penyusunan kelopak kecil warna pink sebanyak 5 buah

- Penyusunan kelopak kecil, mutiara plastik dan peniti ke lempengan

c) Tahap Pemasaran

Pemasaran dengan cara dititipkan ke warung, kopearsi sekolah, pasar, dan lain sebagainya.

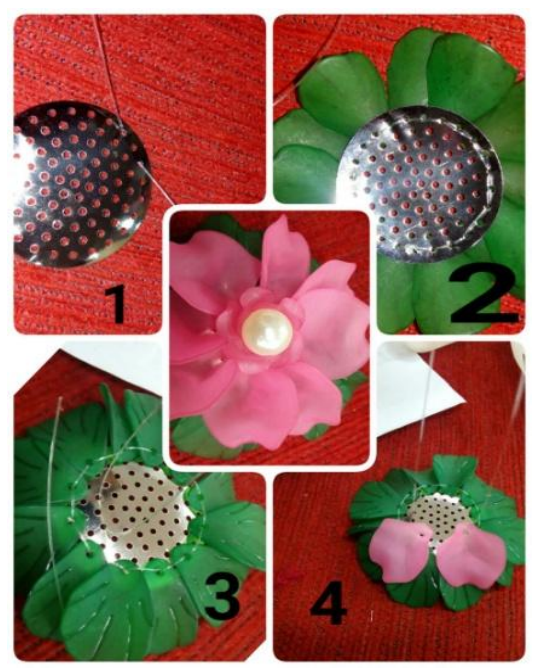

Gambar 3: Langkah pembuatan aksesories

Berdasarkan kegiatan Pengabdian Kepada Masyarakat yang berjudul "Pemberdayaan Ibu-Ibu PKK di Kelurahan Mlati Norowito Dalam Rangka Meningkatkan Pendapatan Keluarga" yang telah dilakukan dilakukan pada Kamis, 15 Desember 2016, dalam wadah komunitas ibu-ibu PKK RW 7 Kelurahan Mlati Norowito, yang mempunyai dua kegiatan utama yaitu: (1) Penyuluhan kewirausahaan (2) Pembekalan warga dengan praktek pembuatan aksesories 
handmade untuk hijab dari bahan acrylick, maka dapat dianalisis sebagai berikut:

a) Beberapa ibu-ibu PKK RW 7 Kelurahan Mlati Norowito sudah memiliki dasar jiwa wirausaha. Hal itu tampak dari adanya beberapa ibu-ibu yang mempunyai usaha sendiri, antara lain adalah usaha warung kelontong di rumah, usaha kerajinan dengan memanfaatkan bank sampah, dan usaha berjualan ikan di pasar.

b) Kendala sebagian ibu-ibu PKK RW 7 Kelurahan Melati Norowito dalam memulai usaha adalah terkait dengan visi dan permodalan. Sehingga tidak sedikit dari mereka yang akhirnya menyerah untuk memulai suatu usaha, dan hidup bergantung dari pendapatan yang diberikan oleh kepala keluarga.

c) Penyuluhan kewirausahaan tersebut, dapat menambah bekal ibu-ibu PKK RW 7 Kelurahan Mlati Norowito dalam memulai usaha, terutama terkait dengan penyusunan visi sbagai dasar usaha yang akan diciptakan, permodalan, dan tahapan yang harus diperhatikan dalam kewirausahaan. Sehingga bekal tersebut dapat digunakan oleh ibu-ibu untuk menambah pendapatan keluarga, dengan memulai suatu usaha baru.

d) Peserta PKK RW 7 Kelurahan Mlati Norowito tampak antusias dalam mengikuti praktek pembuatan aksesories handmade untuk hijab dari bahan acrylick. Hal ini tampak dari adanya seorang peserta yang dapat menyelesaikan praktek tersebut dalam waktu singkat, yaitu Ibu Siti Karamah.

\section{SIMPULAN}

Ibu-ibu PKK RW 7 Kelurahan Mlati Norowito pada dasarnya terbuka dengan setiap ilmu baru terkait dengan ketrampilan yang dapat menghasilkan, dan akhirnya dapat menambah pendapatan keluarga.

$$
\text { Kegiatan Pengabdian Kepada }
$$
Masyarakat yang berjudul "Pemberdayaan Ibu-Ibu PKK di Kelurahan Mlati Norowito Dalam Rangka Meningkatkan Pendapatan Keluarga" melalui 2 kegiatan utama yaitu: (1) Penyuluhan kewirausahaan Pembekalan warga dengan praktek pembuatan aksesories handmade untuk hijab dari bahan acrylick, dapat direspon dengan baik oleh ibu-ibu PKK RW 7 di Kelurahan Mlati Norowito. Sehingga diharapkan jika aksesories handmade untuk hijab dari bahan acrylick tersebut dijual, akan dapat menambah pendapatan keluarga.

Pendapatan keluarga ibu-ibu PKK RW 7 Kelurahan Mlati Norowito juga dapat bertambah dengan diterapkannya hasil penyuluhan kewirausahaan, guna mendukung usaha eksistingnya ataupun 
untuk memulai usaha baru bagi yang belum mempunyai usaha.

\section{SARAN}

Perlu dilanjutkan dengan pelatihan mengenai pemasaran yang lebih memadai seperti mengenalkan e-commerce atau market place dan mengenalkan social media sebagai sarana pemasaran. Lurah Mlati Norowito diharapkan dapat memfasilitasi warganya dhi. ibu-ibu PKK RW 7 atas keterampilan yang dapat menghasilkan dan akhirnya dapat menambah pendapatan keluarga.

\section{UCAPAN TERIMA KASIH}

Ucapan terima kasih disampaikan kepada Bapak Iwan Elliarde, SE. selaku Lurah Mlati Norowito, Yunisih selaku Ketua PKK RW 7, Listiyaningsih selaku tuan rumah, para peserta PKK RW 7, dan tim Pengabdian Kepada Masyarakat, sehingga kegiatan dapat berjalan dengan lancar.

\section{DAFTAR PUSTAKA}

Alma, Buchari. 2010. Kewirausahaan. Bandung: Alfabeta.

Kasmir. 2006. Kewirausahaan Edisi 1. Jakarta: Rajagrafindo Persada
Ruslan, D., \& Budiarta, K. (2017). Pemberdayaan Ekonomi Produktif Masyarakat Miskin di Kota Medan. Jurnal Pembangunan Perkotaan, 5(2), 91-95.

Soediyono, Reksoprayitno. 2009. Ekonomi Makro. Yogyakarta: BPFE UGM.

Wirawan, E. (2009). Analisis Sistem Penjualan Online Berbasis ECommerce (Studi Kasus Pada Crystal Accessories) (Doctoral Dissertation, Prodi Akuntansi Unika Seogijapranata).

www.kuduskab.go.id "Profil Pemerintahan Kabupaten Kudus"

www.koranmuria.com. 2015. "Lurah Mlati Norowito Kudus Bakal Perbaiki Setiap Gang di Wilayahnya."

www.peta-jalan.com Kelurahan/ Desa Mlati Norowito, Kudus Kota, Kab. Kudus.

www.wirabisnis.com. 2015. "Peluang Wirausaha Modal Kecil: Aksesories Hand Made."

www.wikipedia.org Pembinaan Kesejahteraan Keluarga.

Yanti, N. (2014). Meningkatkan Keterampilan Membuat Bros Jilbab Berbentuk Capung Melalui Metoda Latihan pada Anak Tunagrahita Ringan. E-JUPEKhu, 3(2). 